\title{
Hepatitis C virus, alcohol and lipid droplets
}

\author{
Natalia Osna
}

Hepatitis C virus (HCV) persistence drives the progression of $\mathrm{HCV}$ infection. This progression is usually asymptomatic in HCV-infected patients. For many years, clinical manifestations of HCV persistence are restricted to fatty liver followed by slow development of fibrosis, cirrhosis and hepatocellular carcinoma [1, 2]. Thus, HCV persistence is a "first hit" triggering HCV pathogenesis. There are "second hits" that stabilize the infection and cause faster progression, exacerbation of pathological features of $\mathrm{HCV}$ infection and poor response to anti-viral therapy. One of these "second hits" known to affect HCV pathogenesis is alcohol. Liver steatosis is common for both HCV infection and alcohol and is considered as a cofactor in development and progression of fibrosis.

Hepatitis $\mathrm{C}$ virus is an RNA virus packaged into an enveloped virus particle. HCV polyprotein has 3000 amino acids and is co-translational and posttranslational processed by cellular and viral proteases to form three structural proteins (core, E1 and E2), an ion channel protein (p7) and six non-structural proteins ( $\mathrm{NS}_{2}, \mathrm{NS}_{3}$, NS4A, NS4B, NS5A, NS5B) [3]. Viral RNA replication requires the formation of a membrane-associated replication complex composed on HCV non-structural proteins, RNA and cellular membranes. Enveloped HCV virions carrying a newly synthesized viral genome are formed by budding into the endoplasmic reticulum lumen and leave the cells through the secretory transGolgi pathway [4].

\section{Natalia Osna}

Affiliations: Department of Internal Medicine, University of Nebraska Medical Center, Research Service, Veterans Affairs Nebraska-Western lowa Health Care System, Omaha, NE 68105, USA.

Corresponding Author: Natalia Osna, MD, PhD, Internal Medicine, UNMC,Veterans Affairs Nebraska-Western lowa Health Care System,4101 Woolworth Ave, Omaha, NE 68105, USA; Ph: 1-(402) 995-3735; Fax: 1-(402) 449-0604; Email: nosna@unmc.edu

Received: 09 January 2015

Published: 24 January 2015

\section{Lipid Droplets and Infectious HCV Formation}

Structural proteins are released from polyprotein by host signal peptidase. Core protein is further processed by signal peptide peptidase to mature core, and this cleavage promotes the transport of core from the endoplasmic reticulum to the surface of lipid droplets (LD), where the full infectious particle is assembled [5]. In HCV+ cells, core protein is usually detected on the endoplasmic reticulum membrane and at the surface of LD. Core protein encapsulates newly synthesized HCV RNA and by interacting with two surface proteins, E1 and E2, buds into endoplasmic reticulum lumen [6]. The exact mechanism of recruitment of core protein to LDs is not clear. It has been shown that trafficking of core to LD involves Rab18 and that knockdown of Rab18 reduces HCV infectivity [7]. The localization of HCV core protein to LD depends on host diacylglycerol acyltransferase 1 (DGAT1), the enzyme that synthesize triglycerides in endoplasmic reticulum lumen. The abrogation of DGAT1 causes severe impairment in HCV entry [8, 9], and this protein plays a pivotal role in translocation and attachment of core protein to $\mathrm{LD}$, which is crucial for HCV assembly process.

Hepatitis $\mathrm{C}$ virus core protein is a key factor in the regulation of LD accumulation. First, it activates SREBP$1 \mathrm{C}$ and RXR-alpha necessary for lipid biosynthesis [10]. In addition, core protein blocks VLDL secretion by inhibiting microsomal triglyceride transfer protein activity [11] and by induction of peroxidation of lipids and proteins involved in VLDL secretion [12]. Recently, it has been reported that core at the surface of LDs interferes with the activity of adipose triglyceride lipase (ATGL), the key lipolytic enzyme in the first step of triglyceride breakdown, thereby blocking lipolysis [13]. Furthermore, modulation of triglyceride and cholesterol ester synthesis impairs assembly of virus on LDs [14]. Interestingly, there is no difference in the localization of core protein to LDs between HCV genotype 3 (that causes the most severe steatosis) and other HCV genotypes, but genotype 3 induces the largest size of LDs $[15,16]$. HCV corecoated LDs accumulate in the perinuclear region due to expression of core protein's lipid binding domain II (DII- 
core) that slows down LD speed and finally, enhances viral infectivity [17].

Lipid droplets is directly involved in the production of infectious HCV particles. The unique membranous structures ("membranous" web) are detected around the LDs in HCV-producing cells, and significant amount of NS5A protein and HCV RNA are recruited to these LDs. However, the disruption of core protein association with LDs causes a defect in association of $\mathrm{NS}_{5} \mathrm{~A}$ protein and HCVRNA and blocks the virus assembly [10], indicating that the attachment of core protein to LDs recruits nonstructural protein and replication complexes to LDassociated membranes. The attachment of non-structural HCV proteins and recruitment of replication complex is orchestrated by $\mathrm{HCV}$ protein $\mathrm{NS} 2$ by induction of multiple protein-protein interactions. Moreover, NS2 acts to coordinate virus assembly by mediating interactions between envelope proteins and $\mathrm{NS}_{3}$ and $\mathrm{NS}_{5} \mathrm{~A}$ within replication complexes adjacent to LDs, where virus particle assembly is thought to occur [18]. Thus, the role of LDs in the production of infectious HCV particles includes several aspects: HCV replication complex and non-structural proteins are aggregated on LDs. This provides a factor required for infectivity to the virus particle and incorporates virus particle into a vesicle transport system of lipid or lipid-related material to export out of the cells [19].

To our knowledge, there are no published studies on the role of ethanol on LD-associated HCV assembly. We observed a sufficient accumulation of LDs in livers of HCV ethanol-fed core-transgenic mice (unpublished observations) and to lesser extent, in the livers of ethanol-fed NS5A+ mice [20]. Also, in Huh7.5-CYP cells, ethanol and acetaldehyde exposure enhanced amount of LDs, but impaired an expression of core protein on LDs as well as infectivity of cell supernatants. However, the mechanisms of these events are not clear yet, and they remain to be one of uninvestigated, but important areas of HCV-ethanol studies, which are attributed to alcoholinduced progression of liver injury in HCV-infection.

\section{How to cite this article}

Osna N. Hepatitis C virus, alcohol and lipid droplets. Int J Hepatobiliary Pancreat Dis 2015;5:1-3.

Article ID: 100026IJHPDNO2015

$* * * * * * * * *$

doi:10.5348/ijhpd-2015-26-ED-1

\section{Author Contributions}

Natalia Osna - Substantial contributions to conception and design, Acquisition of data, Analysis and interpretation of data, Drafting the article, Revising it critically for important intellectual content, Final approval of the version to be published

\section{Guarantor}

The corresponding author is the guarantor of submission.

\section{Conflict of Interest}

Authors declare no conflict of interest.

\section{Copyright}

(C) 2015 Natalia Osna. This article is distributed under the terms of Creative Commons Attribution License which permits unrestricted use, distribution and reproduction in any medium provided the original author(s) and original publisher are properly credited. Please see the copyright policy on the journal website for more information.

\section{REFERENCES}

1. Jacobson IM, Davis GL, El-Serag H, Negro F, Trepo C. Prevalence and challenges of liver diseases in patients with chronic hepatitis $\mathrm{C}$ virus infection. Clin Gastroenterol Hepatol 2010 Nov;8(11):924-33.

2. Negro F, Sanyal AJ. Hepatitis C virus, steatosis and lipid abnormalities: clinical and pathogenic data. Liver Int 2009 Mar;29 Suppl 2:26-37.

3. Tang H, Grise H. Cellular and molecular biology of HCV infection and hepatitis. Clin Sci (Lond) 2009 Jun 15;117(2):49-65.

4. Fukasawa M. Cellular lipid droplets and hepatitis $\mathrm{C}$ virus life cycle. Biol Pharm Bull 2010;33(3):355-9.

5. McLauchlan J, Lemberg MK, Hope G, Martoglio B. Intramembrane proteolysis promotes trafficking of hepatitis $\mathrm{C}$ virus core protein to lipid droplets. EMBO J 2002 Aug 1;21(15):3980-8.

6. Eggert D, Rosch K, Reimer R, Herker E. Visualization and analysis of hepatitis $C$ virus structural proteins at lipid droplets by super-resolution microscopy. PLoS One 2014 Jul 11;9(7):e102511.

7. Dansako H, Hiramoto H, Ikeda M, Wakita T, Kato $\mathrm{N}$. Rab18 is required for viral assembly of hepatitis C virus through trafficking of the core protein to lipid droplets. Virology 2014 Aug;462-463:166-74.

8. Herker E, Harris C, Hernandez C, et al. Efficient hepatitis $\mathrm{C}$ virus particle formation requires diacylglycerol acyltransferase-1. Nat Med 2010 Nov;16(11):1295-8.

9. Sung PS, Murayama A, Kang W, et al. Hepatitis C virus entry is impaired by claudin-1 downregulation in diacylglycerol acyltransferase-1-deficient cells. J Virol 2014 Aug;88(16):9233-44.

10. Jirasko V, Montserret R, Lee JY, et al. Structural and functional studies of nonstructural protein 2 of the hepatitis C virus reveal its key role as organizer of virion assembly. PLoS Pathog 2010 Dec 16;6(12):e1001233.

11. Perlemuter G, Sabile A, Letteron P, et al. Hepatitis $\mathrm{C}$ virus core protein inhibits microsomal triglyceride 
transfer protein activity and very low density lipoprotein secretion: A model of viral-related steatosis. FASEB J 2002 Feb;16(2):185-94.

12. Negro F. Mechanisms and significance of liver steatosis in hepatitis $\mathrm{C}$ virus infection. World $\mathrm{J}$ Gastroenterol 2006 Nov 14;12(42):6756-5.

13. Camus G, Schweiger M, Herker E, et al. The Hepatitis C Virus Core Protein Inhibits Adipose Triglyceride Lipase (ATGL)-mediated Lipid Mobilization and Enhances the ATGL Interaction with Comparative Gene Identification 58 (CGI-58) and Lipid Droplets. J Biol Chem 2014 Dec 26;289(52):35770-80.

14. Liefhebber JM, Hague CV, Zhang Q, Wakelam MJ, McLauchlan J. Modulation of triglyceride and cholesterol ester synthesis impairs assembly of infectious hepatitis C virus. J Biol Chem 2014 Aug 1;289(31):21276-88.

15. Clément S, Peyrou M, Sanchez-Pareja A, et al. Downregulation of phosphatase and tensin homolog by hepatitis $\mathrm{C}$ virus core $3 \mathrm{a}$ in hepatocytes triggers the formation of large lipid droplets. Hepatology 2011 Jul;54(1):38-49.
16. Qiang G, Jhaveri R. Lipid droplet binding of hepatitis $\mathrm{C}$ virus core protein genotype 3. ISRN Gastroenterol 2012;2012:176728.

17. Lyn RK, Hope G, Sherratt AR, McLauchlan J, Pezacki JP. Bidirectional lipid droplet velocities are controlled by differential binding strengths of HCV core DII protein. PLoS One 2013 Nov 1;8(11):e78065.

18. Ma Y, Anantpadma M, Timpe JM, et al. Hepatitis $\mathrm{C}$ virus NS2 protein serves as a scaffold for virus assembly by interacting with both structural and nonstructural proteins. J Virol 2011 Jan;85(1):86-97.

19. Ogawa K, Hishiki T, Shimizu Y, et al. Hepatitis C virus utilizes lipid droplet for production of infectious virus. Proc Jpn Acad Ser B Phys Biol Sci 2009;85(7):217-8.

20. Osna N, McVicker B, Poluektova L, Ganesan M, Kharbanda K. Mode of Oral Ethanol Feeding Affects Liver Oxidative Stress Levels and Methylation Status: Study on NS5A-TransgenicMice. International Journal of Biochemistry Research \& Review 2014;4(4):344-57.
Access full text article on other devices

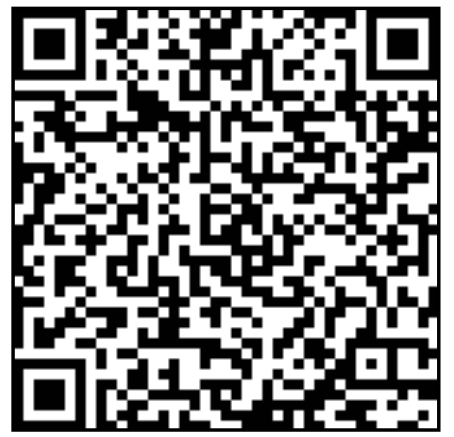

Access PDF of article on other devices

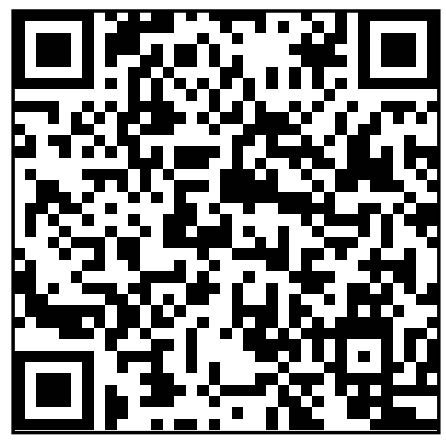

